\title{
Retrieval of a dislodged porth catheter with inaccessible tips in a pediatric cancer patient
}

\author{
Murat Dökdök@
}

To the Editor,

We read the article entitled "Pigtail through snare technique: an easy and fast way to retrieve a catheter fragment with inaccessible ends" with great interest. Here, a modified technique, hooking the catheter fragment with a pigtail catheter advanced through the snare loop, is described by the authors to retrieve the catheter fragment with inaccessible ends in a prompt fashion (Mori et al. 2021). Dislodged venous catheter fragments are retrieved successfully by interventional radiologists for decades using mainly two methods: loop snare or grasping forceps. Besides, other modified adjunct methods with catheters and wires have also been described in the literature. To our best knowledge, using a pigtail catheter positioned to the optimal site when there were no free ends of the catheter was first described by Cheng et al. (2009). They also had utilized basket successfully in patients when tips of the fragments were inaccessible.

There are some other single-center experiences, including relatively small case series in the literature; most of them focus on the materials and complications; none but one reports fluoroscopy time and radiation doses (Kalińczuk et al. 2016). In this study, the median fluoroscopic time reported is $6.1 \mathrm{~min}(0.47-42.0)$, while the maximum dose in the longest procedure entrance skin exposure is $912 \mathrm{mGy}$. However, no specific data was given related to the catheter fragment tip accessibility. We just recently retrieved a dislodged venous port catheter with inaccessible tips in an 8-year old girl who has been treated with medulloblastoma. Venography revealed an embedded proximal catheter tip in the right internal jugular vein wall and an inaccessible distal

Correspondence: Murat.dokdok@anadolusaglik.org

Anadolu Medical Center Hospital affilliated with John's Hopkin, Cumhuriyet M. 2255 S. No 3, 41400 Gebze, Kocaeli, Turkey catheter tip in the right ventricle wall without any free movements. We used a $5 \mathrm{Fr}$ pigtail catheter and 0.035" wire to hook up the central portion of the port catheter, similar to the authors. Then the silicon port catheter was withdrawn from inferior vena cava with $20 \mathrm{~cm}$ Amplatz GooseNeck Snare (Medtronic, USA) through the $6 \mathrm{~F}$ catheter lumen readily. The fluoroscopy time (57 min), air kerma was kept relatively low (734 mGy) using collimators. Compared to radiation doses above study (Kalińczuk et al. 2016), it is relatively low yet still higher than the authors' patient skin dose of $68.12 \mathrm{mGy}$ (Mori et al. 2021) due to longer procedure time.

We think that time and radiation dose should be a major concern, especially when dealing with fragile pediatric patients. Advanced search in PubMed reveals a few case reports in neonates and only two case reports in pediatric cancer patients with venous catheter migration (Elgehiny et al. 2020; Eryilmaz et al. 2012). Neither duration of the procedure nor radiation doses were emphasized in these reports. Since no guideline exists about the dose concerns during such procedures, the principle of 'ALARA' should be implemented in all cases. Although the success of such procedures is quite high, it would be better not to use the trial and error method by trying many different materials which increases the procedure time. After diagnosing an embedded or inaccessible catheter tip, the best strategy should be executed using the appropriate technique.

\section{Acknowledgements \\ Not applicable.}

\section{Author's contributions}

This study was designed and written by the author who performed the procedure. The author(s) read and approved the final manuscript.

\section{Funding}

This study was not supported by any funding.
Springer Open

(c) The Author(s). 2021 Open Access This article is licensed under a Creative Commons Attribution 4.0 International License, which permits use, sharing, adaptation, distribution and reproduction in any medium or format, as long as you give appropriate credit to the original author(s) and the source, provide a link to the Creative Commons licence, and indicate if changes were made. The images or other third party material in this article are included in the article's Creative Commons licence, unless indicated otherwise in a credit line to the material. If material is not included in the article's Creative Commons licence and your intended use is not permitted by statutory regulation or exceeds the permitted use, you will need to obtain permission directly from the copyright holder. To view a copy of this licence, visit http://creativecommons.org/licenses/by/4.0/. 


\section{Availability of data and materials}

The datasets used during the current study are available from the corresponding author on reasonable request.

\section{Declarations}

\section{Ethics approval and consent to participate}

All procedures performed in studies involving human participants were in accordance with the ethical standards of the institutional and/or national research committee and with the 1964 Helsinki declaration and its later amendments or comparable ethical standards. For this type of study formal consent is not required in author's institution; yet, routine informed consent was obtained from individual participant included in the study.

\section{Consent for publication}

Consent for publication was obtained for individual person's data from parent/legal guardian using routine institutional consent form.

\section{Competing interests}

The author declares that he has no competing interest.

Received: 14 May 2021 Accepted: 1 June 2021

Published online: 15 June 2021

\section{References}

Cheng CC, Tsai TN, Yang CC, Han CL (2009) Percutaneous retrieval of dislodged totally implantable central venous access system in 92 cases: experience in a single hospital. Eur J Radiol 69(2):346-350. https://doi.org/10.1016/j.ejrad.2 007.09.034 Epub 2007 Oct 31. PMID: 17976941

Elgehiny A, Ghanem K, Bou Hussein H, Ahmed M, Abohelwa M, Aboelella M, Mohamed M, Bitar F, Abboud M, Akel S, Al-Kutoubi A, Fakhri G, Arabi M (2020) Port-a-Cath fracture and migration in paediatric cancer patients: incidence and management at a tertiary care centre - a 15-year experience. Cardiol Young 30(7):986-990. https://doi.org/10.1017/\$1047951120001390 Epub 2020 Jun 22. PMID: 32624075

Eryilmaz E, Canpolat C, Celiker A (2012) Catheter fragment embolization: a rare yet serious complication of catheter use in pediatric oncology. Turk J Pediatr 54(3):294-297 PMID: 23094542

Kalińczuk Ł, Chmielak Z, Dębski A, Kępka C, Rudziński PN, Bujak S, Skwarek M Kurowski A, Dzielińska Z, Demkow M (2016) Percutaneous retrieval of centrally embolized fragments of central venous access devices or knotted Swan-Ganz catheters. Clinical report of 14 retrievals with detailed angiographic analysis and review of procedural aspects. Postepy Kardiol Interwencyjnej 12(2):140-155. https://doi.org/10.5114/aic.2016.59365 Epub 2016 May 11. PMID: 27279874; PMCID: PMC4882387

Mori K, Somagawa C, Kagaya S, Sakai M, Homma S, Nakajima T (2021) "Pigtail through snare" technique: an easy and fast way to retrieve a catheter fragment with inaccessible ends. CVIR Endovasc 4(1):24. https://doi.org/10.11 86/s42155-021-00218-6 PMID: 33651249; PMCID: PMC7925774

\section{Publisher's Note}

Springer Nature remains neutral with regard to jurisdictional claims in published maps and institutional affiliations.

\section{Submit your manuscript to a SpringerOpen ${ }^{\circ}$ journal and benefit from:}

- Convenient online submission

- Rigorous peer review

- Open access: articles freely available online

- High visibility within the field

- Retaining the copyright to your article

Submit your next manuscript at $\boldsymbol{\nabla}$ springeropen.com 